\title{
Controller involvement in a project management setting: Effects on project functions and performance
}

\author{
Ricardo Malagueño \\ University of East Anglia \\ Norwich Business School \\ Jacobo Gomez-Conde* \\ Universidad Autonoma de Madrid \\ Yannick de Harlez \\ Skema Business School \\ Université Côte d'Azur \\ Olaf Hoffmann \\ Hochschule Konstanz \\ University of Applied Sciences
}

\begin{abstract}
*Corresponding author. Jacobo Gómez-Conde. Departamento de Contabilidad. Universidad Autónoma de Madrid. Fco Tomás y Valiente 5. 28049 Madrid (SPAIN). Tel. +34 91497 3007. E-mail: jacobo.gomez@uam.es
\end{abstract}

We are thankful to two anonymous reviewers and Editor Othmar Lehner for their insightful comments and suggestions. We would like to thank participants at the EAA Annual Congress at Tallinn (2014), and seminar participants of the University of Sao Paulo and IESEG School of Management, Claudio Wanderley, Beatriz Garcia Osma and Gaia Melloni for helpful comments. Jacobo Gomez-Conde acknowledges financial assistance from the Spanish Ministry of Education and Science (ECO201677579-C3-3-P), the Spanish Ministry of Science and Innovation (PID2019-104163RA-I00), the Santander Financial Institute, and the Catedra UAM-Auditores Madrid. 


\title{
Controller involvement in a project management setting: Effects on project functions and performance
}

\author{
Abstract \\ Purpose. We examine the extent to which a controller's involvement in project functions (viz. \\ definition and scope, organization, constraints management, and risk management) cascades \\ down to project performance. \\ Design/methodology/approach. We test our framework using survey data from a sample of \\ project leaders in German and Swiss firms. Responses were analyzed using the partial least \\ squares (PLS) technique.
}

Findings. We find that controllers contribute to project success via the previously described project functions. Further, the study reveals the crucial role of controllers in managing uncertainty and project risks.

Originality. We add to the literature by examining the role of controllers in highly knowledgeintensive, highly pressured, task-driven, interdependent, and dynamic operational settings, thus contributing to a better understanding of how controllers function at an operational level. We also strengthen a broader role of controllers in project management that goes beyond their historical controlling activities to include more modern functions, extending previous studies analyzing their professional identity.

Research limitations. Although the arguments used in this research were not country-specific and suggest that the findings of this study also apply to the controller professional in general, this study clearly acknowledges that further research is needed to address the effects of this role in different jurisdictions given the specific characteristics of controllers acting in Germanspeaking countries.

Practical implications. We provide insights on the role of controllers at an operational level, like project management, highlighting the need for controllers to support an effective project governance.

\section{Keywords}

Project management; cross-functional teams; controllers; management accountants; project functions; project performance.

\section{JEL codes}

M40; M41 


\section{Introduction}

In the last 20 years, research on the organizational role of accountants has shown that controllers $^{1}$ are moving from their traditional, isolated, functional role, usually labeled as number crunchers, into a more innovative, collaborative, cross-functional role as business partners (Järvenpää, 2007; Goretzki et al., 2013; Goretzki et al., 2018; Rouwelaar et al., 2018). While previous research in accounting has documented the modern tendency to increasingly involve controllers in supporting the managerial decision-making at the business unit level (e.g., Hartmann and Maas, 2010; Rouwelaar et al., 2018; Goretzki and Messner, 2019), scholars have dedicated less effort to understanding the active involvement of controllers in operational processes. $^{2}$

The management accounting literature has only marginally addressed the relevance of controller involvement in task-driven, highly pressured, flexible, interdependent, sequential, and dynamic operational settings such as project management (e.g., Nixon, 1998; Nandhakumar and Jones, 2001; Van der Veeken and Wouters, 2002). ${ }^{3}$ Relevant literature in this area concentrates on the use of management accounting information in other settings characterized by high uncertainty such as R\&D and new product development (NPD) (Abernethy and Brownell, 1997; Davila, 2000; Jorgensen and Messner, 2009; Curtis and Sweeney, 2019) or creative environments (Cools et al., 2017; Davila and Ditillo, 2017).

\footnotetext{
${ }^{1}$ The job title "controller" which has a specific professional identity in Germanic regions is equivalent to a "management accountant" in other jurisdictions (Ahrens and Chapman, 2000; Hartmann and Maas, 2011). Thus, similar to Goretzki et al. (2018, p. 723), we employ "controllers" as an "umbrella term" that comprises job titles like management accountant, financial manager or management controllers.

${ }^{2}$ As Goretzki et al. (2013) indicate, the definition of the management accountant is complex, due to the continuous changes in their business roles. But still, there is some consensus in the literature that the controller has moved from the traditional stereotype of "bean counter" (routine work such as registration, data entry and reporting) which seems to have been changed to "business partner," and is now considered as willing and able to provide more added value to decision-making and control (Burns and Baldvinsdottir, 2007; Byrne and Pierce, 2007; Goretzki et al., 2013).

${ }^{3}$ Our study focuses on controllers who report to controlling department or chief financial officers (CFOs) at the business unit level. They are responsible for the financial control function, which includes a supporting role (helping managers in the decision-making process) and a controlling role (assuring the accuracy of financial reports and the integrity of internal controls). Simon et al. (1954) explain that the controller's department may supply (punctually, temporarily or permanently) foremen with information and skills that would help operational managers (such as project managers) in their decision-making process. Therefore, there is a wide range in the "degree" of controllers' involvement in project management.
} 
Previous literature provides some indication of the potential role of controllers in these highly uncertain creative settings (Lee and Wang, 2020). We argue that although some features may overlap with R\&D or NPD contexts, the project management setting is different. Those environments are characterized by well-planned and scheduled tasks, with an increasingly specialized division of labor, and a clear time horizon. Usually, projects have a determined start and end date and the team composition changes very frequently. Consequently, team members have to overcome barriers across functions quickly and need to be open-minded to varying collaboration partners. The interdependence between tasks, links to other systems and sequential decision-making are also important characteristics in a project setting, which means that the problems and deviations in one task affect the others (Zika-Viktorsson et al., 2006). Consequently, the tolerance for project management failure and deviations in performance (e.g., delays and overspending) is lower and the pressure for success higher. ${ }^{4}$ These observed characteristics of project management and the challenges for controlling the things that emerge with them bring an interesting and not fully explored setting to investigate the role of the controller, whose presence in many knowledge-based firms (e.g., information technology (IT) services, auditing, consulting or banking) is growing (CIMA, 2015).

Considering this background, this study examines the extent to which controllers' involvement in project-based settings support project management functions and, consequently, project performance. More precisely, considering this previous background, our study has addressed a key question that remains unresolved in prior studies: How does controller involvement contribute to project management? We refer to this involvement in terms of Byrne and Pierce (2007, p. 471), as a controller "working in cross-functional teams

\footnotetext{
${ }^{4}$ Nakatsu and Iacovou (2009) refer to this question in an IT project management setting, indicating that the lack of integration between tasks is a critical issue in the management of projects. As an example, Raymond and Bergeron (2008) indicate the case of the Canadian Arms Registry, an information system first estimated at "no more than 2 million dollars a year" in 1995, that finally cost close to one billion Canadian dollars 10 years later. These authors also indicate that $75 \%$ of IT projects without proper management and control support will fail.
} 
and on business processes, involvement in decision-making and integrating financial and nonfinancial information on operational and strategic levels." 5,6 To test the hypotheses, we use responses from a structured survey directed at project leaders of knowledge-intensive ${ }^{7}$ German and Swiss companies. Overall, the empirical results support the predictions on the relevance of controller involvement to achieve project success. Thus, our results strengthen a broader role of controllers in project management that goes beyond their historical controlling activities (e.g., organization and evaluation) to include more modern functions (e.g., constraints and risk management).

We aim to contribute to the growing literature on the role of controllers (e.g., Mack and Goretzki, 2017; Horton and Wanderley, 2018). In particular, we add to the scant literature addressing the role of controllers in highly knowledge-intensive and uncertain settings (Ditillo, 2004; Hartmann and Maas, 2011), which is currently highly relevant for academics and practitioners (CIMA, 2018). Hence, this research improves our understanding of how controllers shape operational management (i.e., project management). While the literature primarily assumes that controller involvement is beneficial at a firm-level (Burns and Baldvinsdottir, 2005; Erhart et al., 2017; Rouwelaar et al., 2018), we formulate hypotheses and produce quantitative empirical evidence on the benefits in a project setting (i.e., operationallevel), recognizing different project management functions. There has been relatively little empirical confirmation of this relationship in the literature to date, despite academic calls for further research on this subject (e.g., Bonner et al., 2002) and practitioners call for controllers

\footnotetext{
${ }^{5}$ This is consistent with the advice given by the Charter Institute of Management Accountants (CIMA) and reflected in one of their interviews with a CFO at one of the Big Four accounting firms: "In the future, ... [controllers] will need to be more involved in developing solutions with the rest of the organisation. This is because the function initiates the root cause analysis, and has the understanding that links through to developing solutions. Once the ... [controller] is working with others, it must also move into deploying solutions. Both of these broad areas will require a change in skills focus, from technical and business to problem-solving and change management" (CIMA, 2018, p. 4). Erhart et al. (2017) also refer to this controller involvement in a setting of strategic formation.

${ }^{6}$ Due to the multidimensional nature of project management, we also use field data to identify the project management functions where controllers collaborate. This fieldwork is available from the authors upon request.

${ }^{7}$ Knowledge-intensive organizations refer to "those firms that provide intangible solutions to customer problems by using mainly the knowledge of their individuals" (Ditillo, 2004, p. 401).
} 
to increase their focus on providing expert support for organizational projects (CIMA, 2018). Thus, this study extends prior research by developing our knowledge of the role of controllers at a different level of analysis. Additionally, we aim to contribute to research on project management. Our empirical findings serve as a necessary reminder of the importance of the controller's role in project management to the achievement of the proposed project outcome. Therefore, we add to the literature on project governance (Turner, 2008; Too and Weaver, 2014) by examining the ways in which the different functions of the involvement of controllers assist in project management, contributing to the development of a stronger governance framework at project-level.

\section{Theoretical background}

\subsection{Controller involvement in strategic and operational decision-making}

A large number of researchers have studied how the role of controllers has evolved to attend to the needs of modern organizations (Burns and Baldvinsdottir, 2005; Lambert and Pezet, 2011; Graham et al., 2012; Rouwelaar et al., 2018). As discussed in the introduction, the management accounting literature has acknowledged that the role of controllers has evolved from a traditional and bean-counter archetype to a business partner (Karlsson et al., 2019). The traditional role of controllers as a supporting function that offers financial information and handles accounting tasks (Byrne and Pierce, 2007; De Loo et al., 2011; Karlsson et al., 2019) is well documented in prior research (Hopper, 1980; Friedman and Lyne, 1997; Granlund and Lukka, 1998; Baldvinsdottir et al., 2009; Hartmann and Maas, 2011; Weber, 2011; Linsley and Linsley, 2014).

Contrary to the traditional archetype, recent studies view controllers as a business partner (Zoni and Merchant, 2007; Goretzki et al., 2018). In this vein, controllers are being portrayed as critical counterparts to managers, communicating information and reducing 
asymmetries, scrutinizing problems, and supporting peers or superiors to make better informed decisions (Karlsson et al., 2019). Empirical research indicates that controllers' functional accounting knowledge combined with a profound understanding of the business processes are now used to support decision-making toward the accomplishment of collective goals in different functional areas of the organizations (Horton and Wanderley, 2018). This research highlights the relevance of controller involvement in the strategic and operational decisionmaking processes. Byrne and Pierce (2007) noted that controller involvement helps in simplifying operations into the common language of accounting and translating accounting information into tangible action plans. Other researchers suggested that this involvement entails reliance on financial and accounting information, which promotes rational decisionmaking, thereby preventing the pursuit of ill-conceived and ill-advised courses of action (Heinzelmann, 2018; Rouwelaar et al., 2018). In this vein, prior studies indicate that organizational participants legitimize managerial choices through the use of objective calculations (Järvinen, 2016; Bisbe and Sivabalan, 2017), anchoring cost follow-up routines and arranging face-to-face meetings with hands on activities, to avoid potential breakdowns (Burström and Jacobsson, 2013). Thus, controllers create a more rational and reasonable work decision-making process (Heinzelmann, 2018).

Controller involvement has been recognized as a way of preventing the development of unwanted opportunistic behaviors within an organization, especially in uncertain settings requiring loose forms of control (Chapman, 1998). Erhart et al. (2017) point out the role of controllers' involvement in shaping the strategy formation at a firm-level, by processing data, coordinating different functions, and planning. Goretzki et al. (2018) offer evidence of how the controller handles information and reveal the key role of informational tactics for their everyday work, showing that controllers use these informational tactics (i.e., timing or channeling) to avoid conflicts. 
Although controllers are now expected to collaborate more extensively in the development and execution of strategic plans within cross-functional management groups (Byrne and Pierce, 2007; Erhart et al., 2017), the academic literature provides limited evidence on the controller involvement in an environment where controllers are closer to the actual operations of the firm. Nixon (1998) reported the significant role played by a financial controller in planning and controlling at the project-level. In the project planning phase, the financial controller worked closely with the $R \& D$ design engineers to appraise and minimize the costs of different design possibilities. Additionally, he described an important role of financial controller in cost reporting that supports the project team in balancing the customers' needs with regard to the operating costs and purchase price with the company's contribution and cash flow requirements. Although Nixon's study provides preliminary insights into controller involvement in project management, the author did not aim to examine the role of controllers but the accounting component of R\&D performance measures and the factors that influenced the choice and use of metrics in this setting. Other studies have identified some of the potential contributions of accountants to NPD. Based on a qualitative case study, Burström and Jacobsson (2013) examined the role of controllers in NPD projects. Using an inductive approach, they mainly noted that controllers involved in NPD projects play an important informal liaison role. Additionally, Lee and Wang (2020) identified the possible activities carried out by accountants within the NPD process. The authors examined the moderating role of the business level strategy on the effects of the accountants' activities in NPD performance. Yet the authors paid little attention to the formal role of controllers as business partners in supporting projects. Therefore, the understanding of the impact of controller involvement on project management is still incomplete today despite numerous calls for studies to identify how controllers create value in organizations (Hartmann and Maas, 2011). 


\subsection{Cross-functional collaboration in project management}

A major assumption behind the development of collaborations between organizational participants is that they can help organizations to obtain better managerial performance. Behavioral and economic theories recognize members of an organization as individuals with limited attention and bounded rationality. The decision-making process is restricted by the information and knowledge these members can absorb and process (Lovelace et al., 2001; Cronin and Weingart, 2007; Gomez-Conde et al., 2019). Cross-functional collaboration as a process in which individuals from different functional areas work together, have mutual understanding, share resources, and accomplish collective goals can contribute to the expansion and storage of a vast amount of data (De Luca and Atuahene-Gima, 2007). These data can then be transformed into local, usable information that is then communicated within the organization (West, 2000).

Cross-functional collaboration has been recognized as essential for project success. Projects are temporary endeavors to build a specialized product or service (PMBOK, 2013). The uniqueness of projects and the lack of assurance that plans will deliver the required outcomes or desired beneficial change create high levels of organizational uncertainty. As the complexity of projects, related tasks and technical variables increase, different types of knowledge become necessary (West, 2000). Therefore, cross-functional collaborations are expected to provide expertise in multiple areas that would assist teams and organizations in coping with highly complex problems and projects.

Although cross-functional collaboration has emerged as a structural arrangement that allows organizations to benefit from multiple internal expertise and to respond to unstructured problems, previous studies have identified costs associated with these arrangements. First, researchers have indicated that even collaborative teams composed of highly qualified individuals require participants to unlearn routines, develop new theories of action, and adopt 
new behaviors (Jassawalla and Sashittal, 1999). Second, designing the structural and infrastructural mechanisms necessary for high levels of integration among collaborative groups can be costly and time-consuming (Cuijpers et al., 2011). Finally, previous evidence shows that frictions between different functional backgrounds (e.g., technical and non-technical personnel) and perspectives are commonly observed in cross-functional collaborations (Cronin and Weingart, 2007; Majchrzak et al., 2012). Competing viewpoints, although promoting new creative ideas and sound decision-making, also lead to conflicts, implying time wasting and deteriorating relationships between team members (Edmondson and Nembhard, 2009). Results from case-based research suggest that controllers play the role of peacekeepers, thus facilitating other members to negotiate and come to new solutions (Burström and Jacobsson, 2013).

The consequences of cross-functional collaborations depend to a great extent on the role that team members play in project management (Randel and Jaussi, 2003). Leenders and Wierenga (2002) point out several integrating mechanisms, such as relocation and physical facilities design, use of information and communication technologies, organizational structure or formal integrative management processes, that may reduce the expertise gap or lack of diverging knowledge. Role theory suggests that team roles are determined by other members of the team (Byrne and Pierce, 2007). Team heterogeneity shapes how individuals have an understanding of each other, due to their professional socialization experiences or their "different languages." In this way, role theory also highlights how individuals behave and socialize differently due to a range of singularities, among which are the formation, occupation or position in the organization (Byrne and Pierce, 2007; Biddle, 2013; Espinosa-Pike and Barrainkua, 2020). Project and team members not only specialize in a specific area, but they also develop personal identities that are linked to that area of specialization (Scott, 1997). ${ }^{8}$ Thus, individuals tend to stereotype other members and assume that they do not understand

\footnotetext{
${ }^{8}$ Scott (1997) uses the accountant as a useful example of self-selected social identity.
} 
(Van der Vegt and Bunderson, 2005). Collective identification and integration become a significant aspect of the commitment of each individual, thinking in terms of team goals in addition to their own goals set within their specialty areas (Van der Vegt and Bunderson, 2005). Garlappi et al. (2017) and Adams et al. (2018) show empirical evidence of heterogeneous teams underinvesting in multi-stage projects because they foresee future disagreements or taking more time to make decisions. In summary, whereas there are recognized advantages to having more diverse skills and knowledge on a project, the academic literature has also identified disadvantages in such arrangements, and it is unclear how controller involvement in cross-functional projects relates to project success.

\subsection{Project management functions}

The Project Management Institute defines project management as "the application of knowledge, skills, tools, and techniques to project activities to meet project requirements" (PMBOK, 2013, p. 37). To increase the chances of project success, this Institute recommends that project leaders carefully address project management functions. Although the literature is replete with descriptions of various project management functions, studies identifying the project management functions through which project leaders involve controllers are scarce (Lee-Kelly and Leong, 2003).

Project leaders actually characterize project management functions where the controller involvement is essential in terms of the purposes controllers should fulfill, rather than in terms of individual operational tasks such as budgeting or designing a performance report. Furthermore, these purposes seem to be predominant in the following distinguishable functions (Lee-Kelly and Leong, 2003; Turner, 2008): (i) project definition and scope, (ii) project organization, (iii) project constraints (time, cost, and quality) management, and (iv) project risk management. The main goal of these functions is "to undertake the work of the project and to 
deliver the desired performance improvement at a time and a cost that provides value" (Turner, 2008 , p. 101). Overall these functions contribute to the project governance through the development of structures, including policies, procedures, systems and reports that enhance project success and facilitate the achievement of strategic goals (Too and Weaver, 2014). We succinctly define these functions that have also been developed in previous literature (LeeKelly and Leong, 2003; Too and Weaver, 2014). ${ }^{9}$

Project definition and scope refers to the process of ensuring that a sufficient amount of work is completed (and the unnecessary work is not done), bringing the expected performance improvement. Turner (2008, p. 101) establishes four main steps to deal with the scope management: (i) developing the project's objectives; (ii) defining the scope of work; (iii) authorizing and performing the work, while monitoring and controlling the process; and (iv) ordering the installation to develop the product and achieve the desired benefit. Project organization denotes resource estimation, defining the level and type of inputs (usually human, material and financial), required to achieve the project's objective. According to Turner (2008) managing the project organization also involves adopting a reporting structure that helps build cooperation and ensures the project is brought into operation effectively. Project constraints management includes three main factors: time, cost, and quality. Time refers to managing time and the effort to ensure that this constraint does not cause the failure of the project. Usually, in project management, a schedule is described in order to, for example, coordinate the effort of resources and forecast levels of money and resources, or to ensure that the returns of the project are achieved in a window which gives a reason for the expenditure. The second constraint to manage is cost, through which the financial viability of the product or service is evaluated. There are several reasons for estimating costs, like controlling expenditure on the project, managing cash flows, allocating resources or estimating durations. The last constraint refers to

\footnotetext{
${ }^{9}$ Turner (2008) provides a thorough description of these functions to manage project performance.
} 
quality, in order to ensure that the new project's output meets the specifications and satisfies the customer. Finally, the fourth function is project risk management. This function is meant to reduce risks and protect asset integrity. It refers to the identification of a project's uncertainties, estimation of their impact on the overall project and organization, analysis and control of their interactions within a risk management structure, developing a response plan, and managing these risks. Controllers are knowledgeable accounting professionals who intensify risk awareness such as in discretionary decision-making or in risk control.

Literature on the role of controllers suggest that these professionals contribute to a number of functions within an organization. For instance, Hartmann and Maas (2011) note that controllers play the key role of putting detailed information and data in place to forecast and support the monitoring of schedules and tasks. Prior research identifies metrics, checklists, and models as the most effective ways to increase project success (Amaral Féris et al., 2020). Previous studies have also recognized that controllers assist in the development of the structures that centralize information and organization of teams (Erhart et al., 2017). Finally, controllers, as knowledgeable accounting professionals, are usually able to foresee the potential impact that constraints and uncertainties could have on the achievement of pre-stablished objectives (Byrne and Pierce, 2007), therefore intensifying risk awareness, discretionary decision-making, and risk control (Tekathen and Dechow, 2020). It is noteworthy that controllers do not pursue only one project management function at any given time; rather, they are often pressed to manage various functions simultaneously to guarantee the achievement of project objectives.

\section{Hypothesis development}

This study examines the impact of controller involvement in operational decision-making on project success through different project management functions. We draw on prior 
management and accounting literature to develop hypotheses. Once we have described the project management functions through which the controller can have a potential influence on the project success, we then formulate hypotheses about the relationships between the extent of controller involvement and project performance via different project management functions.

\subsection{Controller involvement, project definition and scope, and project performance}

The project management context poses special difficulties for the effective development and reliance on pre-established targets and objectives (Lenfle and Loch, 2010). Complexity derived from projects requires the tight control of detailed and accurate measures that allow teams to successfully develop project plans. Controllers develop a central role in providing and monitoring financial and non-financial information. These professionals tend to view knowledge mainly in terms of financial information and a corresponding range of non-financial performance metrics (Edwards et al., 2005). Controllers are responsible for ensuring both the accuracy and the reliability of this information (Maas and Matějka, 2009), two quality characteristics that make this data useful for decision-making and control. Thus, in a project context, a more intense controller involvement is associated with the reduction of uncertainties related to the quality of information used to organize the project. Rowe (2004) argues that high task interdependencies, as in a project management setting, usually entail an indetermination of "causal responsibility for gains" and "culpability for losses," derived from free-riding behaviors in the team. Thus, he points out the importance of using information from, and establishing objectives at, the team level in order to reduce negligent and free-riding behaviors. Similarly, controllers provide rationality of decision-making by counterweighting "in the form of reflective management elements to intuitive decisions and initiatives based on business instinct" (Weber and Schäffer, 2019, p. 94). Controllers are willing to stick to the development of formal and detailed company rules, procedures, and norms coercively regulating changes 
(i.e., monitoring, controlling, and formally documenting processes for reviewing, approving, and implementing change requests). As a result, the project management team is encouraged to rely more extensively on key metrics and to establish ex-ante preset values of objectives when there is an intense controller involvement than when there is a limited involvement. Thus, the expertise of controllers and the consequent higher reliance of project teams on metrics and data helps to improve the quality of the development and definition of the objectives of the project, defining the scope of work and associated monitoring of the processes, which are the main steps of project definition and scope.

A properly designed, structured, and reliable plan should increase the chances of a project's success. For instance, a survey conducted by Zwikael and Sadeh (2007) found that better defined and detailed project planning contributes to project success in terms of lower costs, reduced likelihood of a schedule overrun, increased technical performance, and higher customer satisfaction. Thus, project success is highly dependent on the level of effort expended during this function of project definition and scope (Gibson and Hamilton, 1994). ${ }^{10}$

Hla: The extent of controller involvement in project management is positively associated with the quality of project definition and scope.

H1b: The quality of project definition and scope is positively associated with project performance.

\subsection{Controller involvement, project organization, and project performance}

Previous research has acknowledged that management accounting information is an essential part of the project organization (Kasurinen, 2002; Van der Veeken et al., 2002; Dechow et al.,

\footnotetext{
${ }^{10}$ As a powerful example, Gibson and Hamilton (1994) report a $20 \%$ cost savings and a $39 \%$ schedule savings when the level of project definition and scope is high.
} 
2007). Higher and lower-level non-accounting managers use budgets and forecasts, including estimating a multitude of project-related costs and resources involved, determining project plans and budgets and identifying financial risk. However, because each project is unique, management accounting inputs are not exhaustive when estimating the total requirements of a project. This insufficient information highlights the need for close collaboration with knowledgeable controllers. Management accounting information is frequently used by senior managers who provide top-down budget estimates that set out how many resources (usually human, material, and financial) are available for any given project. The role of controllers in translating this information into recommendations for project decision-making is well documented (Goretzki et al., 2013; 2018), offering support in the definition of clear roles and responsibilities for project controlling. Even when informational structures are not formalized, controllers tend to become this central figure that records and consolidates information. Furthermore, a controller involvement in this function contributes to the additional analytical and interpretative skills required to deal with a vast array of information (Burns and Baldvinsdottir, 2005), increasing the knowledge and abilities of project team members (West, 2000). Controllers are regarded as relevant sources of information thanks to their holistic and integrated view $^{11}$ of the project (Ahrens and Chapman, 2000). Mack and Goretzki (2017) refer to the "panoramic knowledge" and the "meta-position" of controllers, based on their interactions with the "specific knowledge" of various individuals, units or projects. A controller involvement in projects enables better and clear organization via calculative comparisons between the actual state of the project versus the expectations presented in the project plan, a more holistic and integrative stance in the interpretation of project requirements and accomplishments, and project teams that are better coordinated in their interdependent tasks. In summary, the controller involvement in the organization function facilitates the

\footnotetext{
${ }^{11}$ Ahrens and Chapman (2000) explain that controllers can participate in potentially very diverse activities with very different organizational meanings, due to their knowledge and personal experience in different areas of the firm.
} 
interpretation of information from a variety of sources, aids in resource estimation and supports decision-making, eventually improving the quality of project organization.

Second, there is abundant research that concludes that better organization at the projectlevel is positively associated with project success (Zwikael et al., 2014). Project managers are usually concerned with a number of decision criteria, particularly in the project organization function, but also in allocating scarce resources to the project development (Speranza and Vercellis, 1993). Each of the activities of the project process can be carried out in multiple and alternative ways, each with a different combination of material, financial, and human resources. Therefore, project managers are requested to organize the most appropriate mode for each task. In doing so, they can obtain acceptable levels of performance in terms of the multiple objectives that are usually in conflict due to the scarcity of resources. This project organization reduces deviations and increases controllability over tasks. Consequently, project organization increases project performance, mainly by reducing unexpected costs and improving time and resource allocation.

H2a: The extent of controller involvement in project management is positively associated with the quality of project organization.

$H 2 b$ : The quality of project organization is positively associated with project performance.

\subsection{Controller involvement, project constraints management, and project performance}

In a project setting, one of the main functions is the management of project constraints. The historical stereotype of accountants (which includes controllers) is that they are skilled with numbers, obsessed with details, defensive, and lacking in both creativity and imagination (Caglio and Cameran, 2018; Rieg, 2018). They are preoccupied with data and target 
achievement (Byrne and Pierce, 2007), and therefore project constraints must be handled. Thus, controllers are usually considered to be policemen, more commonly due to the need to decrease information asymmetry (Hartmann and Maas, 2011) and be able to predict the potential effect that project constraints could have on achieving the objectives. Project constraint management implies taking into account the effect of these constraints in plans, budgets, work standards, and work packages while addressing external and internal conditions as well as inventory levels (PMBOK, 2013). This management is necessary to coordinate activities within teams and help them, for example, to balance customers' needs with the company's parameters regarding operating costs, purchase prices, and cash flow requirements (Nixon, 1998). This ability to anticipate changing or unforeseen circumstances is critical for avoiding cost overruns or schedule delays (Eriksson et al., 2017). We expect that the controller involvement in project management will reduce the importance of adjusting to change once projects have started. Thus, in a project context, a more intense controller involvement is associated with the reduction of uncertainties related to the accuracy, detail, and reliability of information and, as a consequence, with better management of project times, costs or quality.

A project's effectiveness depends to a great extent on how well cross-functional teams manage constraints and how smoothly they coordinate the impact on their activities (Adenfelt, 2010). The decision-makers who receive reliable and detailed status reports about items like cost or time issues are better equipped to allocate resources efficiently and initiate appropriate corrective actions. This accurate and detailed status information helps the project manager in guiding the team toward desirable outcomes.

H3a: The extent of controller involvement in project management is positively associated with the quality of project constraints management. 
H3b: The quality of project constraints management is positively associated with project performance.

\subsection{Controller involvement, project risk management, and project performance}

The risk management practices entail the assessment and control of environmental and technological events (e.g., changes in resource allocation, schedules, working methods, and priorities) that may affect the project's success (Gong and Subramaniam, 2019). Mikes (2009) explains that in the banking sector, risk management activities typically fall under the controlling department and that controllers share similar tasks to risk officers. In a project setting, controllers are not only knowledgeable accounting professionals who increase risk awareness based on the anticipation of financial results, but they are also able to develop several aspects of risk management, such as strategy setting, support in discretionary decision-making, and risk assessment and control. Due to the increasing importance and variety of uncertainties (e.g., poorly defined products, contractors changing specifications and late suppliers and subcontractors), controllers' professional know-how is key so as to compensate for the relative lack of risk management information in the project management system. Additionally, as a project increases in complexity, with more multidisciplinary and cross-functional collaborations, it requires additional efforts and attention to risk management. Divergent knowledge and backgrounds require special attention in terms of risk management. The controller involvement, with their ability to understand the different areas of the project, will make it possible for the different agents involved in the project to understand the effects derived from the decisions they make in their respective areas. Therefore, we expect that a more intense controller involvement is associated with improved quality of risk management.

Empirical findings from several project management studies have suggested that the extent of risk management is associated with the project success rate (Jordan et al., 2013). For 
example, Raz and Michael (2001) provided empirical evidence that companies with a high project management performance used certain project risk management tools (e.g., periodic trend reporting, trend analysis, deviations and exceptions, simulations, subcontractor management, quality management, and responsibility assignment) more extensively than companies with low project management performance. Moreover, previous studies suggest that, without proper risk management, "projects can easily run out of control, consume significant additional resources, greatly inflate project costs and may lead to failure" (Mu et al., 2009, p. 170). Thus, in project management, the diagnosis and management of risks is of vital importance for project success (Keizer et al., 2002; Mu et al., 2009).

H4a: The extent of controller involvement in project management is positively associated with the quality of project risk management.

H4b: The quality of project risk management is positively associated with project performance.

Figure 1 shows the proposed theoretical model.

--Insert Figure 1 about here--

\section{Research and survey design}

\subsection{Sample selection and data collection}

To test the hypotheses, this research relied on empirical data collected via structured surveys administered during interviews with a sample of 59 project leaders working for Swiss and German corporations, from the financial services and engineering industries that were running 
engineering projects. ${ }^{12,13}$ Similar to Maas and Matějka (2009), we limited the target population to controllers working in Switzerland and Germany to control for cultural and institutional differences. Overall, companies were well-established, held front-line positions in their markets, were involved with a high number of projects, and presented well-established procedures for project management. Additionally, companies with a number of employees above 50 were taken into account to ensure that structures of control were present. Table 1 presents demographic data. Sample organizations display a mean (median) of $7,874(1,800)$ employees and 17.03 (15) months of project duration. Overall, 82\% of participants revealed that they have sufficient resources (i.e., training and tools) to carry out their projects and, in general, controllers' knowledge and skills are ranked as average.

--Insert Table 1 about here--

Three sources were used to select participant companies: the Swiss Project Management Association, the database of the Alumni-Network of a Swiss university, and a "snowball" approach with interviewees ${ }^{14}$ (i.e., interviewees identified other potential participants through their social network), like in some previous studies in accounting (Lander et al., 2013; Groen et al., 2017). The first contact was via email or telephone through which 52 face-to-face interviews were organized and six were conducted via telephone. Interviews lasted, on average, 1.5-2.0 hours and were structured around a set of questions. The questions, similar to previous literature (Lyons and Skitmore, 2004; Maas and Matějka, 2009), asked about the company's project management, on average: formal control systems, cross-functional

\footnotetext{
12 Our sample size is similar to previous studies analyzing functions of management accounting (i.e., Bisbe and Otley, 2004; Bisbe and Malagueño, 2009; Burkert and Lueg, 2013). Burkert and Lueg (2013) indicate that non-archival studies on management accounting controls have a median response of $n=62$.

${ }^{13}$ As a robustness test, we include a control variable measuring industry. Untabulated results yield similar effects.

${ }^{14}$ We contacted 68 companies, but nine of them did not agree to participate in the research project.
} 
collaborations, project management functions, and project performance. No incentives were provided for participating in the survey. The interviewees' ages ranged from 35 to 45 and they were very experienced and knowledgeable about project management and collaboration with controllers. Harman's one-factor test did not reveal the presence of common method effects in the survey data.

\subsection{Variables measurement}

Controller involvement. This construct measures the extent of controller involvement in projects using six items that assess the controllers' project awareness, the involvement of controllers in a project's decision-making, and the frequency of interactions between controllers and project teams. The instrument was partially adapted from Luo et al. (2006) and Erhart et al. (2017).

Quality of project definition and scope. Five dimensions were taken into account when measuring the quality of project definition and scope, namely: (i) standards for project evaluation, (ii) that project standards were followed and put into practice, (iii) the four-eyes principle, ${ }^{15}$ (iv) relevant and reliable project data, and (v) project schedule for work package.

Quality of project organization. It measures the extent to which the roles and responsibilities and resource estimations were defined and detailed, and the necessary ex-ante project resource estimation assessments carried out. The instrument comprises three items: (i) clear roles and responsibilities, (ii) central project controlling function, and (iii) a project assessment carried out before the project start.

Quality of project constraints management. Based on Blackstone et al. (2009) project constraints management was measured using four items that capture: (i) quality constraints, (ii)

\footnotetext{
15 The 4-eyes principle refers to the system in which certain activity must be approved by at least two people. This is a controlling mechanism used to increase project transparency.
} 
time constraints, and (iii) cost constraints. More specifically, the first item measures the relevance of constraints related to technical specifications on managing the project. The second item measures the relevance of constraints related to schedule. Finally, two items measure the relevance of constraints related to profitability and budget.

Quality of project risk management. Drawing on Hallikas et al. (2002) and $\mathrm{Mu}$ et al. (2009), the quality of the project risk management was captured with three indicators measuring how frequently risks were assessed, how clearly risk management was defined, and how quickly a response occurred after the risk was identified.

Project performance. Adapted from Shenhar and Dvir (1996), it measures the degree to which stated goals and milestones were completed (i.e., our scales offer a range of percentages about project objectives) and used to capture project performance, including: (i) the percentage of projects that were finalized, (ii) specifications met, (iii) no time delays, and (iv) completed within budget.

Finally, uncertainty, project duration, and organizational size are used as control variables. These additional variables in the model are intended to control for factors that could affect the project performance and the project management functions and could also be correlated with the controller involvement, and mainly based on previous literature. Uncertainty was measured using items related to (i) technical uncertainty and (ii) market uncertainty. We refer to uncertainty as the difference between what project managers possess and the information necessary to determine end-user requirements (Liu et al., 2011). Project duration was measured using a single question about the time a typical project takes for completion. Previous literature recognizes project duration as a key factor in project management, indicating that the effectiveness of the project team is higher in long-term projects (Zwikael and Unger-Aviram, 2010). Finally, organizational size was measured by the 
number of employees in the firm. Previous results suggest that greater organizational structures are positively related to project performance (Cobo-Benita et al., 2016).

\section{Results}

We use partial least squares (PLS) to test the hypotheses. ${ }^{16}$ The proposed research model was analyzed and interpreted in two stages: (i) assessment of the reliability and validity of the measurement model, and (ii) assessment of the structural model.

\subsection{Measurement model}

The reliability and validity of the survey scales were tested. Table 2 presents an abbreviated version of the questionnaire as well as descriptive scale statistics and measurement model parameters. The output from PLS related to the measurement model shows a high loading (greater than 0.70 ) of all items on their respective constructs. A few items loaded marginally below 0.70 in some of the tests. ${ }^{17}$ Internal consistency reliability was assessed using composite reliability (CR) and the average variance extracted (AVE). As shown in Table 2, the CR values indicate a good consistency of all constructs, when using the threshold of 0.7 (Nunnally, 1978). The percentage of total variance in a construct that is extracted by the AVE should be greater than 0.50 . Constructs were in the $0.510-0.718$ range, indicating adequate convergent validity.

--Insert Table 2 about here--

\footnotetext{
${ }^{16}$ In this study we use the software SmartPLS.

${ }^{17}$ One item of project performance (completed within budget) displayed a low loading $(<0.5)$, and hence is dropped from the analysis. Retaining this item has no substantive effect on the results of our analysis. For items with loadings between 0.5 and 0.7, we choose to keep them in the measurement model, as in previous literature (Bedford, 2015; Garcia Osma et al., 2018; Gomez-Conde et al., 2019).
} 
Discriminant validity is analyzed by comparing the AVE of each construct and the variance shared with other constructs in the model. Table 3 shows that the square root of the AVEs (in the diagonal) is greater than the respective correlations between constructs in the corresponding columns and rows, demonstrating satisfactory discriminant validity. ${ }^{18}$ We did not detect signs of multicollinearity, since the highest correlation is 0.606 .

--Insert Table 3 about here--

Overall, these results from the PLS measurement model indicate satisfactory reliability and validity.

\subsection{Hypotheses test results: Structural model}

Given that the measurement models displayed satisfactory results, the second step is to estimate the structural model by applying the PLS algorithm. A bootstrapping procedure with 1,500 subsamples is performed to test the statistical significance of path coefficients. The results are shown in Table 4 and Figure 2.

H1a predicts a positive association between controller involvement in project management and the quality of project definition and scope. As shown in Table 4 and Figure 2 , the path coefficient is positive and significant $(\beta=0.288, \mathrm{p}<0.05)$, providing support for H1a. $\mathrm{H} 1 \mathrm{~b}$ states that the quality of project definition and scope is positively associated with project performance. Results indicate a significant and positive association with project performance $(\beta=0.314, \mathrm{p}<0.05)$. Therefore, $\mathrm{H} 1 \mathrm{~b}$ is supported.

\footnotetext{
${ }^{18}$ As an additional test of discriminant validity, we assess whether each item has a higher loading on the assigned construct than on the other constructs. We report these results in Appendix B.
} 
$\mathrm{H} 2 \mathrm{a}$ predicts the association between the controller involvement and the quality of project organization. The path coefficient is positive and significant $(\beta=0.356, p<0.05)$, providing support for H2a. The association between the quality of project organization and project performance is also significant $(\beta=0.240, \mathrm{p}<0.05)$; hence, $\mathrm{H} 2 \mathrm{~b}$ is supported.

$\mathrm{H} 3 \mathrm{a}$ states a positive association between controller involvement and the quality of project constraints management. Results show a positive and significant path coefficient $(\beta=0.423, p<0.01)$. Results also display a significant association of the quality of project constraints management with project performance $(\beta=0.523, \mathrm{p}<0.01)$. Thus, H3a and H3b are supported.

As predicted in $\mathrm{H} 4 \mathrm{a}$, the results show that the controller involvement in project management has a significant positive association with the quality of project risk management $(\beta=0.359, p<0.01)$. Contrary to what is expected in $H 4 b$, the quality of project risk management is non-significantly associated with project performance $(\beta=-0.050, p>0.10)$.

Table 4 also shows that the control variables influence the quality of project management functions and project performance. Uncertainty is negatively associated with project performance, while organizational size and project duration do not show significant relationships. Related to project management functions, organizational size increases the quality of project constraints management. Additionally, both project duration and organizational size reduce the quality of project organization.

$\mathrm{R}^{2}$ for dependent variables were also displayed in Table 4 . As the aim of PLS is to maximize variance explained rather than fit, we use $\mathrm{R}^{2}$ to evaluate the PLS models. $\mathrm{R}^{2}$ is greater than 0.2 for all but one dependent variable, which is 0.175 (for quality of project definition and scope). A high $\mathrm{R}^{2}(0.619)$ is obtained for the model with a dependent variable project performance, and project management functions as independent variables. Finally, all variance 
inflation factors (VIFs) are well below the recommended threshold of 10, indicating that the threat of collinearity is not a concern in our data.

--Insert Table 4 about here--

--Insert Figure 2 about here-

The design of our research model opens the question of the indirect association between controller involvement and project performance. For completeness, we explore this link. Untabulated results indicate that controller involvement increases project performance through the quality of project definition and scope $(\beta=0.090, \mathrm{p}<0.10)$, project organization $(\beta=0.085$, $\mathrm{p}<0.10)$, and project constraints management $(\beta=0.221, \mathrm{p}<0.01)$. Results show a nonsignificant effect through the quality of project risk management $(\beta=-0.018, p>0.10)$. Overall, the total indirect effect reported in PLS shows a positive and significant association of controller involvement on project performance through project functions $(\beta=0.379, \mathrm{p}<0.01)$.

\subsection{Additional results: The role of market uncertainty on the quality of project risk} management

An interesting result is the non-significant association between the quality of project risk management and project performance. To understand this unexpected result, we focus on an additional driver of project performance: uncertainty, which we also display in Table 4 and in line with the work of Ditillo (2004). Results in Table 5 show that the interaction between the quality of project risk management and uncertainty is negative and significant $(\beta=-0.201$, $\mathrm{p}<0.10$ ). This result suggests that under high uncertainty, project risk and risk quantification are more difficult to manage. In contrast, under low uncertainty, the risk management function 
allows a quick identification of challenges and a quicker response to problems than in high uncertainty projects.

--Insert Table 5 about here--

\section{Discussion and conclusions}

This study's objective was to explore how the controller involvement contributes to project management. To address this research question, we focused on the controller involvement in project management and examine the impact of this involvement on four project management functions and, sequentially, on project performance. A partial least squares (PLS) analysis of survey data collected from project leaders working for Swiss and German corporations produced several findings.

Overall, we found that controllers play an important role in project management. More specifically, this research shows that the controller involvement in project management affects project management functions that, in turn, have an impact on project performance. This general finding is consistent with prior behavioral and economic literature arguing that crossfunctional collaboration allows projects to benefit from multiple internal expertise and to respond to unstructured problems in highly knowledge-intensive and uncertain context. In addition, this is a finding consistent with role theory and the prediction that the formal role of controllers within a project team is to support the operational decision-making process by bringing up unique set of information and knowledge to organizational participants with limited attention and bounded rationality.

Our results inform previous research on the role of controllers in highly knowledgeintensive and uncertain settings in two main ways. First, the controller involvement is not restricted to one specific phase of project management but should become an integral part of a 
project from inception to completion. Hence, controllers support the project definition and scope or project organization at the early stages of project management by improving the quality of plans, and also enhancing the quality of project constraints management and risk management in the execution phase. Results provide evidence of the role of controllers as providers of information for sophisticated investment appraisal and project selection (Nixon et al., 2011) and also for project integration, as they tend to play the key role of putting KPIs and standards of evaluation in place to monitor project performance. Furthermore, a closer controller involvement in the planning process (e.g., project definition and scope or project organization) contributes to the additional analytical and interpretative skills required to deal with a vast array of information (Burns and Baldvinsdottir, 2005).

Second, this study reinforces a broader role of controllers in project management that goes beyond their historical activities (e.g., planning and monitoring KPIs) to include more modern activities (e.g., risk management). Thus, as shown in the results, standardized coefficients effects are larger for the project organization, the project constraints management, and project risk management. Overall, this implies that controllers are still valued not only for their traditional controlling knowledge and capabilities, but also for their more recently described roles (i.e., risk management). These results confirm the idea that the role of the controller is not limited to control but also "to encourage people to project themselves in the near and far future, to identify new trends, to see new opportunities and threats" (Davila et al., 2009, p. 296), and to build upon prior management accounting studies that have stated that controller involvement is always beneficial for mitigating corporate control problems and helping top-level managers to make decisions (Hartmann and Maas, 2010).

Related to managerial and economic implications, our findings provide practitioners with the arguments for controller involvement in project management. The conceptual model we propose highlights how controllers support project governance through the fulfilment of 
several functions that reflect on project success. Whereas controller involvement requires time, effort and, usually, resources, their role supports project management and facilitates crosscollaborations within projects by offering not only information for decision-making, but also rationality with hands on activities. In addition, prior research also demonstrates the importance of project success in increasing overall business success, providing evidence for project management practitioners and for business managers for the high relevance of this process in economic numbers (Ekrot et al., 2016).

Although arguments presented in this study suggest that higher quality of risk management improves project performance, this was not supported by the surveyed sample. Risk management requires procedures and documentation but, according to Power (2009) or Jordan et al. (2013), managers might focus the attention on representations that guard them from external critique. This "external focus" potentially beneficial to the project. Thus, risk management can promote a defensive and blame avoidance culture, affecting the success of the project. In the additional results, we report that the association between the quality of risk management and project performance is positive for projects under low uncertainty. We attribute these results to the fact that these projects are subject to fewer changes, and the information and communication do have a positive and significant relationship with performance, showing an effect of reducing information asymmetries and slack. With the same reasoning, this association is less evident in the high uncertainty projects. Uncertainty requires freedom to promote new ideas and novel approaches and then experiment with new solutions that are, at times, outside the scope of the formal preset objectives. There is a perception that the type of mindset required to establish and monitor targets of risk in a perceived strict and narrow way is, in fact, detrimental to the project's success. Thus, an open question is the explicitness of the risk management and performance

\footnotetext{
${ }^{19}$ Jordan et al. (2013) label it as "secondary risk" management.
} 
parameters and how project managers choose to recognize and respond to these when facing and juggling a number of uncertainties (Cheng et al., 2018; Gong and Subramaniam, 2019).

Finally, even though the arguments used in this research were not country-specific and suggest that the findings of this study also apply to the controller professional in general, this study clearly acknowledges that further research is needed to address the effects of this role in different jurisdictions given the specific characteristics of controllers acting in Germanspeaking countries. Rieg (2018) points out that controllers are a long and active community in Germany, seeing themselves as the active partners of managers, which could have some implications in the results we have obtained. Additionally, while a survey is a useful way to investigate the role of controllers in a project management setting, this method necessarily precludes a detailed understanding of their function in any individual project. We use a snowballing approach to obtain data; although it is not a concern in qualitative research, generalization of our findings will be made with caution. Lastly, although our sample size is similar to several previous studies in management accounting, the statistical power of our survey only allows us to identify large and medium-sized links (Burkert and Lueg, 2013; Gomez-Conde and Lopez-Valeiras, 2018). Future research should investigate these relationships and model in larger databases. 


\section{References}

Abernethy, M. A., and P. Brownell, 1997. Management control systems in research and development organizations: the role of accounting, behavior and personnel controls. Accounting, Organizations and Society, 22(3), 233-248.

Adams, R. B., A. C. Akyol, and P. Verwijmeren, 2018. Director skill sets. Journal of Financial Economics, 130, 641-662.

Adenfelt, M., 2010. Exploring the performance of transnational projects: shared knowledge, coordination and communication. International Journal of Project Management, 28(6), 529-538.

Ahrens, T., and C. Chapman, 2000. Occupational identity of management accountants in Britain and Germany. European Accounting Review, 9(4), 477-498.

Amaral Féris, M. A., K. Goffin, O. Zwikael, and D. Fan, 2020. Enhancing software development through project-based learning and the quality of planning. $R \& D$ Management. In press.

Baldvinsdottir, G., J. Burns, H. Nørreklit, and R. W. Scapens, 2009. The image of accountants: From bean counters to extreme accountants. Accounting, Auditing, \& Accountability Journal, 22(6), 858-882.

Bedford, D. S., 2015. Management control systems across different modes of innovation: Implications for firm performance. Management Accounting Research, 28, 12-30.

Biddle, B. J., 2013. Role theory: Expectations, identities, and behaviors. Academic Press.

Bisbe, J. and P. Sivabalan, 2017. Management control and trust in virtual settings: A case study of a virtual new product development team. Management Accounting Research, 37, 1229.

Bisbe, J., and D. Otley, 2004. The effects of the interactive use of management control systems on product innovation. Accounting, Organizations and Society, 29(8), 709-737.

Bisbe, J., and R. Malagueño, 2009. The choice of interactive control systems under different innovation management modes. European Accounting Review, 18(2), 371-405.

Blackstone Jr, J. H., J. F. Cox III, and J. G. Schleier Jr, 2009. A tutorial on project management from a theory of constraints perspective. International Journal of Production Research, 47(24), 7029-7046.

Bonner, J. M., R. W. Ruekert, and O. C. Walker Jr, 2002. Upper management control of new product development projects and project performance. Journal of Product Innovation Management, 19(3), 233-245.

Burkert, M., and R. Lueg, 2013. Differences in the sophistication of Value-based Management - The role of top executives. Management Accounting Research, 24, 3-22.

Burns, J., and G. Baldvinsdottir, 2005. An institutional perspective of accountants' new roles: the interplay of contradictions and praxis. European Accounting Review, 14(4), 725-757.

Burström, T. and M. Jacobsson, 2013. The informal liaison role of project controllers in new product development projects. International Journal of Managing Projects in Business, 6(3), 410-424.

Byrne, S., and B. Pierce, 2007. Towards a more comprehensive understanding of the roles of management accountants. European Accounting Review, 16(3), 469-498.

Caglio, A., and M. Cameran, 2018. Is it shameful to be an accountant? GenMe perception(s) of accountants' ethics. Abacus, 53(1), 1-27.

Chapman, C. S., 1998. Accountants in organizational networks. Accounting, Organizations and Society, 23(8), 737-766.

Cheng, M. M., K. A. Humphreys, and Y. Y. Zhang, 2018. The interplay between strategic risk profiles and presentation format on managers' strategic judgments using the balanced scorecard. Accounting, Organizations and Society, 70, 92-105. 
CIMA, 2015. Essentials of project Management. A practical refresher. Chartered Institute of Management Accountants (CIMA). Available at: https://www.cimaglobal.com/Documents/Research\%20and\%20Insight/projectmanagement-tool.pdf

CIMA, 2018. The changing role and mandate of finance: Creating a vision for the future research emerging themes. https://www.cgma.org/content/dam/cgma/resources/reports/downloadabledocuments/cha nging-role-mandate-finance-cgma.pdf

Cobo-Benita, J.R., E. Rodríguez-Segura, I. Ortiz-Marcos, and L. Ballesteros-Sánchez, 2016. Innovation projects performance: Analyzing the impact of organizational characteristics. Journal of Business Research, 69(4), 1357-1360.

Cools, M., K. Stouthuysen, and A. Van den Abbeele, 2017. Management control for stimulating different types of creativity: The role of budgets. Journal of Management Accounting Research, 29(3), 1-21.

Cronin, M. A., and L. R. Weingart, 2007. Representational gaps, information processing, and conflict in functionally diverse teams. Academy of Management Review, 32(3), 761-773.

Cuijpers, M., H. Guenter, and K. Hussinger, 2011. Costs and benefits of inter-departmental innovation collaboration. Research Policy, 40(4), 565-575.

Curtis, E., and B. Sweeney, 2019. Flexibility and control in managing collaborative and inhouse NPD. Journal of Accounting \& Organizational Change, 15(1), 30-57.

Davila, A., 2000. An empirical study on the drivers of management control systems design in new product development. Accounting, Organizations and Society, 25(4-5), 383-410.

Davila, A., and A. Ditillo, 2017. Management control systems for creative teams: managing stylistic creativity in fashion companies. Journal of Management Accounting Research, 29(3), 27-47.

Davila, A., G. Foster, and D. Oyon, 2009. Accounting and control, entrepreneurship and innovation: venturing into new research opportunities. European Accounting Review, $18(2), 281-311$.

De Loo, I., B. Verstegen, and D. Swagerman, 2011. Understanding the roles of management accountants. European Business Review, 23(3), 287-313.

De Luca, L. M., and K. Atuahene-Gima, 2007. Market knowledge dimensions and crossfunctional collaboration: examining the different routes to product innovation performance. Journal of Marketing, 71, 95-112.

Dechow, N., M. Granlund, and J. Mouritsen, 2006. Management control of the complex organization: relationships between management accounting and information technology, in C. S. Chapman, A. G. Hopwood and M. D. Shields, ed., Handbooks of management accounting research, 2 (Elsevier), 625-640.

Ditillo, A., 2004. Dealing with uncertainty in knowledge-intensive firms: the role of management control systems as knowledge integration mechanisms. Accounting, Organizations and Society, 29(3), 401-421.

Edmondson, A. C., and I. M. Nembhard, 2009. Product development and learning in project teams: The challenges are the benefits. Journal of Product Innovation Management, 26(2), $123-138$.

Edwards, J. S., P. M. Collier, and D. C. Shaw, 2005. Research Report on Knowledge Management and its Impact on the Management Accountant. London: CIMA Publishing.

Ekrot, B., A. Kock, and H. G. Gemünden, 2016. Retaining project management competence - Antecedents and consequences. International Journal of Project Management, 34, $145-157$. 
Erhart, R., M. D. Mahlendorf, M. Reimer, and U. Schäffer, 2017. Theorizing and testing bidirectional effects: The relationship between strategy formation and involvement of controllers. Accounting, Organizations and Society, 61, 36-52.

Eriksson, P. E., J. Larsson, O. Pesämaa, 2017. Managing complex projects in the infrastructure sector - A structural equation model for flexibility-focused project management. International Journal of Project Performance, 35, 1512-1523.

Espinosa-Pike, M., and Barrainkua, I. (2020). Professional accountants in Spain: a comparative study of ethical and professional values. Spanish Journal of Finance and Accounting / Revista Española de Financiación y Contabilidad, 49(2), 234-264.

Friedman, A., and S. Lyne, 1997. Activity-based techniques and the death of the bean counter. European Accounting Review, 6, 19-44.

Garcia Osma, B., J. Gomez-Conde, and E. de las Heras, 2018. Debt pressure and interactive use of control systems: Effects on cost of debt. Management Accounting Research, 40, 2746.

Garlappi, L., R. Giammarino, and A. Lazrak, 2017. Ambiguity and the corporation: Group disagreement and underinvestment. Journal of Financial Economics, 125, 417-433.

Gibson, G., and M. Hamilton, M., 1994. Analysis of pre-project planning and success variables for capital facility projects. A report to the Construction Industry Institute, University of Texas at Austin, source document 105.

Gomez-Conde, J., and E. Lopez-Valeiras, 2018. The dual role of management accounting and control systems in exports: drivers and payoffs. Spanish Journal of Finance and Accounting, 47(3), 307-328.

Gomez-Conde, J., R. Lunkes, and F. Rosa, 2019. Environmental innovation practices and operational performance. The joint effects of management accounting and control systems and environmental training. Accounting, Auditing \& Accountability Journal, 32(5), 13251357.

Gong, M. Z. and N. Subramaniam, 2019. Principal leadership style and school performance: mediating roles of risk management culture and management control systems use in Australian schools. Accounting \& Finance. In press.

Goretzki, L., E. Strauss, and J. Weber, 2013. An institutional perspective on the changes in management accountants' professional role. Management Accounting Research, 24, 4163.

Goretzki, L., K., and M. Messner, 2019. Backstage and frontstage interactions in management accountants' identity work. Accounting, Organizations and Society, 74, 1-20.

Goretzki, L., K., Lukka, and M. Messner, 2018. Controllers' use of informational tactics. Accounting and Business Research, 48(6), 700-726.

Graham, A., S. Davey-Evans, and I. Toon, 2012. The developing role of the financial controller: evidence from the UK. Journal of Applied Accounting Research, 13(1), 71-88.

Granlund, M., and K. Lukka, 1998. Towards increasing business orientation: Finnish management accountants in a changing cultural context. Management Accounting Research, 9(2), 185-211.

Groen, B. A. C., M. J. F. Wouters, and C. P. M. Wilderom, 2017. Employee participation, performance metrics, and job performance: A survey study based on self-determination theory. Management Accounting Research, 36, 51-66.

Hallikas, J., V-M. Virolainen, and M. Tuominen, 2002. Risk analysis and assessment in network environments: a dyadic case study. International Journal of Production Economics, 78, 45-55.

Hartmann, F. G. H., and V. S. Maas, 2010. Why business unit controllers create budget slack: involvement in management, social pressure, and Machiavellianism. Behavioral Research in Accounting, 22(2), 27-49. 
Hartmann, F. G. H., and V. S. Maas, 2011. The effects of uncertainty on the roles of controllers and budgets: an exploratory study. Accounting and Business Research, 41(5), 439-458.

Heinzelmann, R., 2018. Occupational identities of management accountants: the role of the IT system. Journal of Applied Accounting Research, 19(4), 465-482.

Hopper, T. M., 1980. Role conflicts of management accountants and their position within organization structures. Accounting, Organizations and Society, 5(4), 401-411.

Horton, K. E., and C. A. Wanderley, 2018. Identity conflict and the paradox of embedded agency in the management accounting profession: Adding a new piece to the theoretical jigsaw. Management Accounting Research, 38, 39-50.

Järvenpää, M., 2007. Making business partners: A case study on how management accounting culture was changed. European Accounting Review, 16(1), 99-142.

Järvinen, J. T., 2016. Role of management accounting in applying new institutional logics: A comparative case study in the non-profit sector. Accounting, Auditing \& Accountability Journal, 29(5), 861-886.

Jassawalla, A. R., and H. C. Sashittal, 1999. Building collaborative cross-functional new product teams. Academy of Management Executive, 13(3), 50-63.

Jordan, S., L. Jørgensen, and H. Mitterhofer, 2013. Performing risk and the project: Risk maps as mediating instruments. Management Accounting Research, 24, 156-174.

Jørgensen, B., and M. Messner, 2009. Management control in new product development: the dynamics of managing flexibility and efficiency. Journal of Management Accounting Research, 21, 99-124.

Karlsson, B., M. Kurkkio, and A. Hersinger, 2019. The role of the controller in strategic capital investment projects: bridging the gap of multiple topoi. Journal of Management and Governance, 23, 813-818.

Kasurinen, T., 2002. Exploring management accounting change: the case of balanced scorecard implementation. Management Accounting Research, 13, 323-343.

Keizer, J. A., J. I. M. Halman, and M. Song, 2002. From experience: applying the risk diagnosing methodology. Journal of Product Innovation Management, 19, 213-232.

Lambert, C., and E. Pezet, 2011. The making of the management accountant: becoming the producer of truthful knowledge. Accounting Organizations and Society, 36, 10-30.

Lander, M. W., B. A. S. Koene, and S. N. Linssen, 2013. Committed to professionalism: Organizational responses of mid-tier accounting firms to conflicting institutional logics. Accounting, Organizations and Society, 38(2), 13-148.

Lee, C. L., and W. Y. Wang, 2020. Strategy, accountants' activities and new product development performance. Advances in Accounting, 50, 100487.

Lee-Kelly, L., and K. L. Leong, 2003. Turner's five functions of project-based management and situational leadership in IT services projects. International Journal of Project Management, 21, 583-591

Leenders, M. A., and B. Wierenga, 2002. The effectiveness of different mechanisms for integrating marketing and R\&D. Journal of Product Innovation Management, 19(4), 305317.

Lenfle, S., and C. Loch, 2010. Lost roots: how project management came to emphasize control over flexibility and novelty. California Management Review, 53, 32-55.

Linsley, P., and A. Linsley, 2014. Cultural theory of risk and the motion of "management accountants as strategists. In D. T. Otley and K. Soin (Eds.), Management control and uncertainty (pp. 224-238).Palgrave Macmillan.

Liu, J. Y-C., H-G. Chen, C. C. Chen, and T. S. Sheud, 2011. Relationships among interpersonal conflict, requirements uncertainty, and software project performance. International Journal of Project Management, 29(5), 547-556. 
Lovelace, K., D. L. Shapiro, and L. R. Weingart, 2001. Maximizing cross-functional new product teams' innovativeness and constraint adherence: A conflict communications perspective. Academy of Management Journal, 44(4), 779-793.

Luo, X., R. J. Slotegraaf, and X. Pan, 2006. Cross-functional coopetition: the simultaneous role of cooperation and competition within firms. Journal of Marketing, 70(2), 67-80.

Lyons, T., and M. Skitmore, 2004. Project risk management in the Queensland engineering construction industry: a survey. International Journal of Project Management, 22, 51-61.

Maas, V. S., and M. Matějka, 2009. Balancing the dual responsibilities of business unit controllers: field and survey evidence. The Accounting Review, 84(4), 1233-1253.

Mack, S., and L. Goretzki, 2017. How management accountants exert influence on managersa micro-level analysis of management accountants' influence tactics in budgetary control meetings. Qualitative Research in Accounting \& Management, 14(3), 328-362.

Majchrzak, A., P. H. More, and S. Faraj, 2012. Transcending knowledge differences in crossfunctional teams. Organization Science, 23(4), 951-970.

Mikes, A., 2009. Risk management and calculative cultures. Management Accounting Research, 20, 18-40.

Mu, J., G. Peng, and D. L. MacLachlan, 2009. Effect of risk management strategy on NPD performance. Technovation, 29(3), 170-180.

Nakatsu, R. T., and C. L. Iacovou, 2009. A comparative study of important risk factors involved in offshore and domestic outsourcing of software development projects: A two-panel Delphi study. Information \& Management, 46(1), 57-68.

Nandhakumar, J., M. Jones, 2001. Accounting for time: managing time in project-based teamworking. Accounting, Organizations and Society, 26(3), 193-214.

Nixon, B., 1998. Research and development performance measurement: a case study. Management Accounting Research, 9(3), 329-355.

Nixon, B., J. Burns, and M. Jazayeri, 2011. The Role of Management Accounting in New Product Design and Development Decisions. London: CIMA Publishing.

Nunnally, J. C., 1978. Psychometric theory. Nueva York: Mc Graw Hill.

Power, M., 2009. The risk management of nothing. Accounting, Organizations and Society, 34, 849-855.

Project Management Body of Knowledge (PMBOK), 2013. A Guide to the Project Management Body of Knowledge, 5th ed. Newtown Square, PA: Project Management Institute.

Randel, A., and K. S. Jaussi, 2003. Functional background identity, diversity, and individual performance in cross-functional teams. Academy of Management Journal, 46(6), 763-774.

Raymond, L., and F. Bergeron, 2008. Project management information systems: An empirical study of their impact on project managers and project success. International Journal of Project Management, 26(2), 213-220.

Raz, T., and E. Michael, 2001. Use and benefits of tools for project risk management. International Journal of Project Management, 19, 9-17.

Rieg, R., 2018. Tasks, interaction and role perception of management accountants: Evidence from Germany. Journal of Management Control, 29(2), 183-220.

Rouwelaar, H. ten, J. Bots, and I. De Loo, 2018. The influence of management accountants on managerial decisions. Journal of Applied Accounting Research, 19(4), 442-464.

Rowe, C., 2004. Effect of accounting report structure and team structure on performance in cross-functional teams. The Accounting Review, 79(4), 1153-1180.

Scott, S. G. (1997). Social identification effects in product and process development teams. Journal of Engineering Technology and Management, 14(2), 97-127.

Shenhar, A. J., and D. Dvir, 1996. Towards a typological theory of project management. Research Policy, 25 (4), 607-632. 
Simon, H. A., 1954. Centralization vs. decentralization in organizing the controller's department: A research study and report (No. 4). Controllership Foundation.

Speranza, M. G., and C. Vercellis, 1993. Hierarchical models for multi-project planning and scheduling. European Journal of Operational Research, 64(2), 312-325.

Tekathen, M. and N. Dechow, 2020. Semantic narrowing in risk talk: The prevalence of communicative path dependency. Management Accounting Research, p.100692.

Too, E. G., and P. Weaver, 2014. The management of project management: A conceptual framework for project governance. International Journal of Project Management, 32(8), $1382-1394$.

Turner, J. R., 2008. The handbook of project-based management. Leading strategic change in organizations. Third ed. London: McGraw-Hill.

Van der Veeken, H. J. M., and M. J. F. Wouters, 2002. Using accounting information systems by operations managers in a project company. Management Accounting Research, 13(3), 345-370.

Van der Vegt, G. S, and J. S. Bunderson, 2005. Learning and performance in multidisciplinary teams: the importance of collective team performance. Academy of Management Journal, $48(3), 532-547$.

Weber J., and U. Schäffer. 2019. Is ensuring management rationality a controlling task?. In: Schäffer U. (eds) Behavioral Controlling. Springer Gabler, Wiesbaden.

Weber, J., 2011. The development of controller tasks: Explaining the nature of controllership and its changes. Journal of Management Control, 22(1), 25-46.

West, J., 2000. Institutions, information processing, and organization structure in research and development: evidence from the semiconductor industry. Research Policy, 29(3), 349373.

Zika-Viktorsson, A., P. Sundström, and M. Engwall, 2006. Project overload: An exploratory study of work and management in multi-project settings. International Journal of Project Management, 24, 385-394.

Zoni, L., and K. A. Merchant, 2007. Controller involvement in management: an empirical study in large Italian corporations. Journal of Accounting \& Organizational Change, 3(1), 2943.

Zwikael, O., and A. Sadeh, 2007. Planning effort as an effective risk management tool. Journal of Operations Management, 25(4), 755-767.

Zwikael, O., and E. Unger-Aviram, 2010. HRM in project groups: The effect of project duration on team development effectiveness. International Journal of Project Management, 28, 413-421.

Zwikael, O., R. D. Pathak, G. Singh, and S. Ahmed, 2014. The moderating effect of risk on the relationship between planning and success. International Journal of Project Management, $32(3), 435-441$. 


\section{Appendix A- Abbreviated survey}

\section{Controller involvement}

Please consider the complete course of a project [in your company]. To what extent do you agree with the following descriptions? ( 1 = Strongly agree; 6 = Strongly disagree) (reverse coded)

- Controllers can participate in the project

- Controllers can be involved in the decision-making process

- Controllers collaborate extensively within the project team

- Controllers participate in the project team (e.g., business case creation)

- Controllers participate in meetings (e.g., review meetings)

- Controllers receive information on a regular basis about the project

Quality of project definition and scope

When planning a project, some things are difficult to assess in advance. Please consider the complete course of a project [in your company]. To what extent do you agree with the following descriptions? $(1=$ Strongly agree; $6=$ Strongly disagree) (reverse coded)

- There are uniform standards for project evaluation

- Project standards are followed and put into practice

- Four-eyes principle for project evaluation in definition phase

- Relevant and reliable project planning data

- Project schedule for work package

Quality of project organization

To what extent do the following statements reflect your organization's project management organization? $(1=$ Always; $6=$ Never) (reverse coded)

- We have clear roles and responsibilities for project controlling and organization

- We have a central project controlling function that centrally records the status of projects, creates consolidated reporting, and defines standards for reporting

- Project assessment before project start is relevant (e.g., creating cost-accounting)

Quality of project constraints management

To what extent do the following items are relevant to manage your project? $(1=$ Always; $6=$ Never) (reverse coded)

- Technical specifications

- Compliance schedules

- Project profitability

- Compliance with the project budget

Quality of project risk management

To what extent do the following statements reflect your organization's project management style? $(1=$ Always; $6=$ Never) (reverse coded)

- Regular project risk assessment

- Project risk management is a clear, defined process

- Quick response to problems within projects

Project performance

Please consider the following percentages of project: $(<50 \%,>50-60 \%,>60-70 \%,>80-70 \%,>90-99 \%, 100 \%)$

- How many projects that started were completed?

- Among these completed projects, in general, how many requirements were met?

- How many projects were completed without time delays?

- Among the completed projects, how many met projected budget estimations using a small margin (> 5\%) of difference between pre-and post-budget calculations?

Uncertainty

Type of the projects that are typically handled $(1=$ Always; $6=$ Never $)$ (reverse coded $)$

- We are dealing with large uncertainties due to technical challenges

- We are dealing with large uncertainties due to customer-or market-specific challenges 


\section{Appendix B- Discriminant validity}

Table A. Discriminant validity. Cross-loadings

\begin{tabular}{|c|c|c|c|c|c|c|}
\hline & $\begin{array}{l}\text { Controller } \\
\text { involvement }\end{array}$ & $\begin{array}{l}\text { Quality of project } \\
\text { definition and } \\
\text { scope }\end{array}$ & $\begin{array}{c}\text { Quality of } \\
\text { project } \\
\text { organization }\end{array}$ & $\begin{array}{l}\text { Quality project } \\
\text { constraints } \\
\text { management }\end{array}$ & $\begin{array}{c}\text { Quality of } \\
\text { project risk } \\
\text { management }\end{array}$ & $\begin{array}{c}\text { Project } \\
\text { performance }\end{array}$ \\
\hline Controllers participate in projects & 0.844 & 0.283 & 0.361 & 0.366 & 0.313 & 0.145 \\
\hline Controllers are involved in the decision-making process & 0.850 & 0.269 & 0.330 & 0.378 & 0.302 & 0.158 \\
\hline Controllers collaborate extensively within the project team & 0.741 & 0.168 & 0.230 & 0.425 & 0.223 & 0.114 \\
\hline Controllers participate in the project team & 0.810 & 0.267 & 0.302 & 0.398 & 0.320 & 0.216 \\
\hline Controllers participate in project meetings & 0.879 & 0.288 & 0.301 & 0.461 & 0.223 & 0.224 \\
\hline Controllers receive info on a regular basis about the project & 0.782 & 0.148 & 0.259 & 0.339 & 0.229 & 0.046 \\
\hline Standards for project evaluation & 0.279 & 0.882 & 0.401 & 0.366 & 0.440 & 0.445 \\
\hline Project standards are followed and put into practice & 0.201 & 0.894 & 0.308 & 0.419 & 0.417 & 0.494 \\
\hline Four-eyes principle & 0.247 & 0.643 & 0.120 & 0.096 & 0.332 & 0.170 \\
\hline Relevant and reliable project planning data & 0.264 & 0.613 & 0.313 & 0.180 & 0.484 & 0.282 \\
\hline Project schedule for work package & 0.066 & 0.535 & 0.046 & 0.348 & 0.146 & 0.292 \\
\hline Clear roles and responsibility & 0.216 & 0.436 & 0.778 & 0.225 & 0.341 & 0.377 \\
\hline Central project controlling function & 0.121 & 0.268 & 0.775 & 0.113 & 0.156 & 0.367 \\
\hline Project assessment before project start & 0.415 & 0.089 & 0.589 & 0.251 & 0.148 & 0.234 \\
\hline Implementation of technical specifications (quality) & 0.183 & 0.055 & 0.098 & 0.552 & 0.076 & 0.222 \\
\hline Compliance schedules (time) & 0.222 & 0.341 & 0.186 & 0.741 & 0.270 & 0.484 \\
\hline Project profitability & 0.416 & 0.386 & 0.389 & 0.752 & 0.306 & 0.471 \\
\hline Compliance with the projected budget (cost) & 0.404 & 0.326 & 0.190 & 0.838 & 0.123 & 0.440 \\
\hline Regular risk assessment & 0.098 & 0.447 & 0.168 & 0.122 & 0.696 & 0.280 \\
\hline Clear, defined process & 0.294 & 0.450 & 0.368 & 0.261 & 0.885 & 0.324 \\
\hline Quick response to identified risks & 0.310 & 0.209 & 0.093 & 0.222 & 0.609 & 0.143 \\
\hline Percentage of project completed & 0.200 & 0.405 & 0.357 & 0.425 & 0.247 & 0.819 \\
\hline Percentage of project meeting specifications & 0.123 & 0.430 & 0.348 & 0.497 & 0.301 & 0.891 \\
\hline Percentage of project without time delays & 0.079 & 0.090 & 0.360 & 0.196 & 0.215 & 0.558 \\
\hline
\end{tabular}

Discriminant validity on item level required that an item loading (in italics and bold) should be higher that all of its cross-loadings 
Table 1. Sample descriptives

\begin{tabular}{lcccc}
\hline & Mean & Median & Standard deviation & Min-Max \\
\hline Number of employees & $7,874.86$ & 1,800 & $15,495.04$ & $55-70,000$ \\
Project duration & 17.03 & 15.00 & 5.16 & $7.50-24.00$ \\
Project complexity & 2.16 & 2.00 & 1.26 & $1-6$ \\
Internal project & 0.56 & 1.00 & 0.50 & $0-1$ \\
Project resources & 0.82 & 1.00 & 0.39 & $0-1$ \\
Controller knowledge and skills & 3.10 & 3.00 & 1.11 & $1-6$ \\
Importance of the controller function & 3.27 & 3.00 & 1.28 & $1-6$ \\
Top management team support to controller & 2.85 & 3.00 & 1.24 & $1-6$ \\
\hline
\end{tabular}

Number of employees $=$ number of employees per unit/subsidiary; Project duration = project duration in months (average); Project complexity $=6$-point Likert scale from low (1) to high (6); Internal project $=$ Dummy variable that equals 1 if the project was internal; 0 if the project was external; Project resources = Dummy variable that equals 1 if the organization invested many resources in project management-related training and tools; Controller knowledge and skills = 6-point Likert scale from low (1) to high (6); Importance of the controller function = 6-point Likert scale from low (1) to high (6); Top management team support to controller =6-point Likert scale from low (1) to high (6). 
$\underline{\text { Table 2. Questionnaire items, descriptive scale statistics, loadings and reliability }}$

\begin{tabular}{|c|c|c|c|c|c|c|c|c|}
\hline & Theoretical range & Practical range & Mean & Median & $\mathrm{SD}$ & Loadings & $\mathrm{CR}$ & AVE \\
\hline \multicolumn{9}{|l|}{ Controller involvement } \\
\hline Controllers can participate in the project & $1.00-6.00$ & $1.00-6.00$ & 4.17 & 4.00 & 1.60 & 0.844 & \multirow[t]{6}{*}{0.924} & \multirow[t]{6}{*}{0.671} \\
\hline Controllers involved in the decision-making process & $1.00-6.00$ & $1.00-6.00$ & 4.07 & 4.00 & 1.66 & 0.850 & & \\
\hline Controllers collaborate extensively within the project team & $1.00-6.00$ & $1.00-6.00$ & 4.07 & 4.00 & 1.54 & 0.741 & & \\
\hline Controllers participate in the project team & $1.00-6.00$ & $1.00-6.00$ & 3.93 & 4.00 & 1.61 & 0.810 & & \\
\hline Controllers participate in meetings & $1.00-6.00$ & $1.00-6.00$ & 3.00 & 3.00 & 1.64 & 0.879 & & \\
\hline Controllers receive info. on a regular basis about the project & $1.00-6.00$ & $1.00-6.00$ & 5.03 & 5.00 & 1.27 & 0.782 & & \\
\hline \multicolumn{9}{|l|}{ Quality of project definition and scope } \\
\hline Standards for project evaluation & $1.00-6.00$ & $1.00-6.00$ & 4.85 & 5.00 & 1.53 & 0.882 & \multirow[t]{5}{*}{0.831} & \multirow[t]{5}{*}{0.510} \\
\hline Project standards are followed and put into practice & $1.00-6.00$ & $1.00-6.00$ & 4.42 & 5.00 & 1.32 & 0.894 & & \\
\hline Four-eyes principle & $1.00-6.00$ & $1.00-6.00$ & 4.82 & 6.00 & 1.67 & 0.643 & & \\
\hline Relevant and reliable project planning data & $1.00-6.00$ & $1.00-5.00$ & 4.41 & 5.00 & 0.99 & 0.613 & & \\
\hline Project schedule for work package & $1.00-6.00$ & $1.00-6.00$ & 5.13 & 5.00 & 1.09 & 0.535 & & \\
\hline \multicolumn{9}{|l|}{ Quality of project organization } \\
\hline Clear roles and responsibility & $1.00-6.00$ & $1.00-6.00$ & 4.29 & 4.00 & 1.45 & 0.778 & \multirow[t]{3}{*}{0.763} & \multirow[t]{3}{*}{0.525} \\
\hline Central project controlling function & $1.00-6.00$ & $1.00-6.00$ & 4.94 & 5.00 & 5.00 & 0.775 & & \\
\hline Project assessment before project start & $1.00-6.00$ & $1.00-6.00$ & 4.93 & 5.00 & 1.23 & 0.589 & & \\
\hline \multicolumn{9}{|l|}{ Quality of project constraints management } \\
\hline Implementation of technical specifications (quality) & $1.00-6.00$ & $3.00-6.00$ & 4.90 & 5.00 & 0.94 & 0.552 & \multirow[t]{4}{*}{0.819} & \multirow[t]{4}{*}{0.535} \\
\hline Compliance schedules (time) & $1.00-6.00$ & $2.00-6.00$ & 5.20 & 5.00 & 0.87 & 0.741 & & \\
\hline Project profitability & $1.00-6.00$ & $2.00-6.00$ & 4.85 & 5.00 & 0.98 & 0.752 & & \\
\hline Compliance with the projected budget (cost) & $1.00-6.00$ & $2.00-6.00$ & 5.00 & 5.00 & 1.00 & 0.838 & & \\
\hline \multicolumn{9}{|l|}{ Quality of project risk management } \\
\hline Regular risk assessment & $1.00-6.00$ & $1.00-6.00$ & 4.66 & 5.00 & 1.15 & 0.696 & \multirow[t]{3}{*}{0.779} & \multirow[t]{3}{*}{0.546} \\
\hline Clear, defined process & $1.00-6.00$ & $1.00-6.00$ & 3.94 & 4.00 & 1.56 & 0.885 & & \\
\hline Quick response to identified risks & $1.00-6.00$ & $1.00-6.00$ & 3.61 & 4.00 & 1.40 & 0.609 & & \\
\hline \multicolumn{9}{|l|}{ Project performance } \\
\hline Percentage of project completed & $1.00-6.00$ & $1.00-6.00$ & 4.64 & 5.00 & 1.34 & 0.819 & \multirow[t]{3}{*}{0.755} & \multirow[t]{3}{*}{0.531} \\
\hline Percentage of project meeting specifications & $1.00-6.00$ & $1.00-6.00$ & 3.86 & 4.00 & 1.24 & 0.891 & & \\
\hline Percentage of project without time delays & $1.00-6.00$ & $1.00-6.00$ & 2.88 & 3.00 & 1.66 & 0.558 & & \\
\hline
\end{tabular}

SD: standard deviation; CR: composite reliability; AVE: average variance extracted. 
Table 2. Questionnaire items, descriptive scale statistics, loadings and reliability (cont'd)

\begin{tabular}{|c|c|c|c|c|c|c|c|c|}
\hline & Theoretical range & Practical range & Mean & Median & SD & Loadings & $\mathrm{CR}$ & AVE \\
\hline \multicolumn{9}{|l|}{ Uncertainty } \\
\hline Technical uncertainty & $1.00-6.00$ & $1.00-6.00$ & 3.03 & 3.00 & 1.39 & 0.949 & 0.834 & 0.718 \\
\hline Market uncertainty & $1.00-6.00$ & $1.00-6.00$ & 3.36 & 3.00 & 1.43 & 0.732 & & \\
\hline \multicolumn{9}{|l|}{ Project duration } \\
\hline Project duration & NA & $7.50-24.00$ & 17.03 & 15.00 & 5.16 & NA & NA & NA \\
\hline $\begin{array}{l}\text { Organizational size } \\
\text { Number of employees }\end{array}$ & NA & $55-70,000$ & $7,874.86$ & 1,800 & $15,495.04$ & NA & NA & NA \\
\hline
\end{tabular}

SD: standard deviation; CR: composite reliability; AVE: average variance extracted; NA: not applicable. 
Table 3. Inter-Construct Correlations and Square Root of AVE statistics ${ }^{\mathrm{a}}$

\begin{tabular}{|c|c|c|c|c|c|c|c|c|c|}
\hline 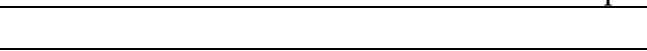 & 1 & 2 & 3 & 4 & 5 & 6 & 7 & 8 & 9 \\
\hline 1. Controller involvement & 0.819 & & & & & & & & \\
\hline 2. Quality of project definition and scope & 0.301 & 0.714 & & & & & & & \\
\hline 3. Quality of project organization & 0.353 & 0.387 & 0.725 & & & & & & \\
\hline 4. Quality of project constraints management & 0.467 & 0.398 & 0.253 & 0.731 & & & & & \\
\hline 5. Quality of project risk management & 0.329 & 0.567 & 0.311 & 0.270 & 0.739 & & & & \\
\hline 6. Project performance & 0.188 & 0.571 & 0.460 & 0.606 & 0.345 & 0.729 & & & \\
\hline 7. Organizational size & 0.207 & 0.069 & -0.134 & 0.435 & -0.101 & 0.117 & 1.000 & & \\
\hline 8. Project duration & -0.231 & -0.272 & -0.319 & -0.022 & -0.254 & -0.046 & -0.036 & 1.000 & \\
\hline 9. Uncertainty & 0.142 & -0.205 & 0.460 & 0.102 & -0.216 & -0.159 & 0.191 & 0.245 & 0.847 \\
\hline
\end{tabular}


$\underline{\text { Table 4. Path model test results }}$

\begin{tabular}{|c|c|c|c|c|c|}
\hline & $\begin{array}{c}\text { Quality of project } \\
\text { definition and } \\
\text { scope }\end{array}$ & $\begin{array}{l}\text { Quality of project } \\
\text { organization }\end{array}$ & $\begin{array}{l}\text { Quality of project } \\
\text { constraints management }\end{array}$ & $\begin{array}{c}\text { Quality of project risk } \\
\text { management }\end{array}$ & Project performance \\
\hline Controller involvement & $\begin{array}{c}0.288^{* *} \\
(2.053)\end{array}$ & $\begin{array}{l}0.356^{* *} \\
(2.234)\end{array}$ & $\begin{array}{c}0.423 * * * \\
(3.096)\end{array}$ & $\begin{array}{c}0.359 * * * \\
(2.649)\end{array}$ & \\
\hline Quality of project definition and scope & & & & & $\begin{array}{l}0.314 * * \\
(2.030)\end{array}$ \\
\hline Quality of project organization & & & & & $\begin{array}{c}0.240 * * \\
(2.008)\end{array}$ \\
\hline Quality of project constraints management & & & & & $\begin{array}{c}0.523 * * * \\
(3.804)\end{array}$ \\
\hline Quality of project risk management & & & & & $\begin{array}{c}-0.050 \\
(0.415)\end{array}$ \\
\hline Control variables & & & & & \\
\hline Organizational size & $\begin{array}{c}0.046 \\
(0.286)\end{array}$ & $\begin{array}{c}-0.198^{* *} \\
(2.216)\end{array}$ & $\begin{array}{c}0.361 * * \\
(2.236)\end{array}$ & $\begin{array}{c}-0.140 \\
(1.286)\end{array}$ & $\begin{array}{l}-0.071 \\
(0.607)\end{array}$ \\
\hline Project duration & $\begin{array}{c}-0.150 \\
(1.219)\end{array}$ & $\begin{array}{c}-0.221^{*} \\
(1.835)\end{array}$ & $\begin{array}{c}0.102 \\
(0.880)\end{array}$ & $\begin{array}{l}-0.125 \\
(0.803)\end{array}$ & $\begin{array}{c}0.149 \\
(1.329)\end{array}$ \\
\hline Uncertainty & $\begin{array}{c}-0.218 \\
(1.232)\end{array}$ & $\begin{array}{c}-0.093 \\
(0.654)\end{array}$ & $\begin{array}{c}-0.052 \\
(0.402)\end{array}$ & $\begin{array}{c}-0.209 \\
(1.208)\end{array}$ & $\begin{array}{c}-0.149^{*} \\
(1.621)\end{array}$ \\
\hline $\mathrm{R}^{2}$ & 0.175 & 0.235 & 0.347 & 0.209 & 0.619 \\
\hline $\mathrm{R}^{2}$ adjusted & 0.114 & 0.179 & 0.299 & 0.150 & 0.567 \\
\hline Max VIF & 1.154 & 1.154 & 1.154 & 1.154 & 1.780 \\
\hline
\end{tabular}

T-statistics in parentheses are based on bootstrapping (1,500 samples with replacement) 
$\underline{\text { Table 5. Path model test results. Additional analysis of uncertainty effects }}$

\begin{tabular}{|c|c|c|c|c|c|}
\hline - & $\begin{array}{c}\text { Quality of project } \\
\text { definition and } \\
\text { scope }\end{array}$ & $\begin{array}{l}\text { Quality of project } \\
\text { organization }\end{array}$ & $\begin{array}{l}\text { Quality of project } \\
\text { constraints management }\end{array}$ & $\begin{array}{l}\text { Quality of project risk } \\
\text { management }\end{array}$ & $\begin{array}{c}\text { Project } \\
\text { performance }\end{array}$ \\
\hline Controller involvement & $\begin{array}{l}0.288 * * \\
(2.019)\end{array}$ & $\begin{array}{l}0.356^{* *} \\
(2.226)\end{array}$ & $\begin{array}{c}0.423 * * * \\
(3.306)\end{array}$ & $\begin{array}{l}0.359 * * * \\
(2.673)\end{array}$ & \\
\hline Quality of project definition and scope & & & & & $\begin{array}{c}0.298 * * \\
(1.993)\end{array}$ \\
\hline Quality of project organization & & & & & $\begin{array}{c}0.256^{* *} \\
(2.354)\end{array}$ \\
\hline Quality of project constraints management & & & & & $\begin{array}{c}0.557 * * * \\
(4.351)\end{array}$ \\
\hline Quality of project risk management & & & & & $\begin{array}{l}-0.095 \\
(0.797)\end{array}$ \\
\hline Quality of project risk management $x$ Uncertainty & & & & & $\begin{array}{l}-0.201^{*} \\
(1.819)\end{array}$ \\
\hline Control variables & & & & & \\
\hline Organizational size & $\begin{array}{c}0.046 \\
(0.298)\end{array}$ & $\begin{array}{c}-0.198 * * \\
(2.059)\end{array}$ & $\begin{array}{l}0.361 * * \\
(2.194)\end{array}$ & $\begin{array}{l}-0.140 \\
(1.298)\end{array}$ & $\begin{array}{l}-0.094 \\
(0.860)\end{array}$ \\
\hline Project duration & $\begin{array}{l}-0.150 \\
(1.177)\end{array}$ & $\begin{array}{l}-0.221^{*} \\
(1.763)\end{array}$ & $\begin{array}{c}0.102 \\
(0.831)\end{array}$ & $\begin{array}{l}-0.125 \\
(0.762)\end{array}$ & $\begin{array}{c}0.139 \\
(1.342)\end{array}$ \\
\hline Uncertainty & $\begin{array}{l}-0.218 \\
(1.353) \\
\end{array}$ & $\begin{array}{l}-0.093 \\
(0.663) \\
\end{array}$ & $\begin{array}{l}-0.052 \\
(0.391) \\
\end{array}$ & $\begin{array}{l}-0.209 \\
(1.269) \\
\end{array}$ & $\begin{array}{l}-0.178^{*} \\
(1.724) \\
\end{array}$ \\
\hline$\overline{\mathrm{R}^{2}}$ & 0.175 & 0.235 & 0.347 & 0.209 & 0.654 \\
\hline $\mathrm{R}^{2}$ adjusted & 0.114 & 0.179 & 0.299 & 0.150 & 0.599 \\
\hline Max VIF & 1.154 & 1.154 & 1.154 & 1.154 & 1.787 \\
\hline
\end{tabular}

T-statistics in parentheses are based on bootstrapping (1,500 samples with replacement). 


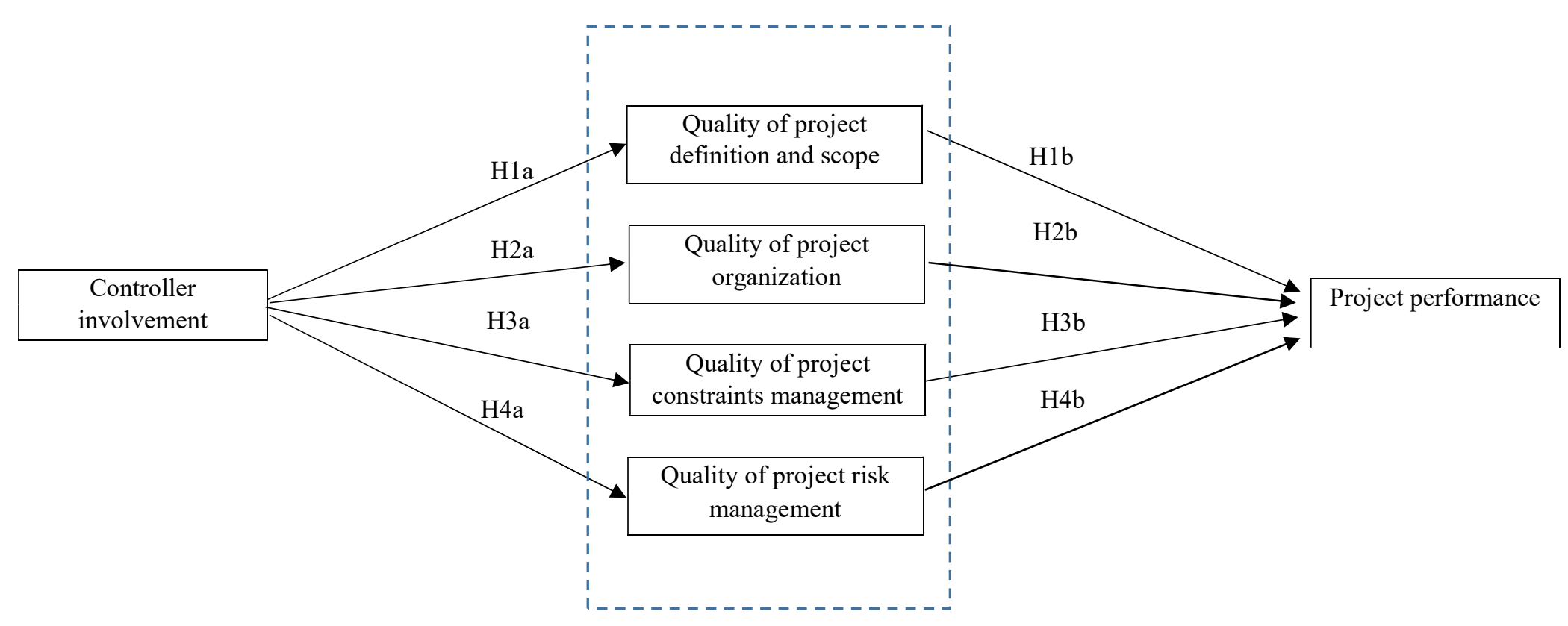

Figure 1. Theoretical model 


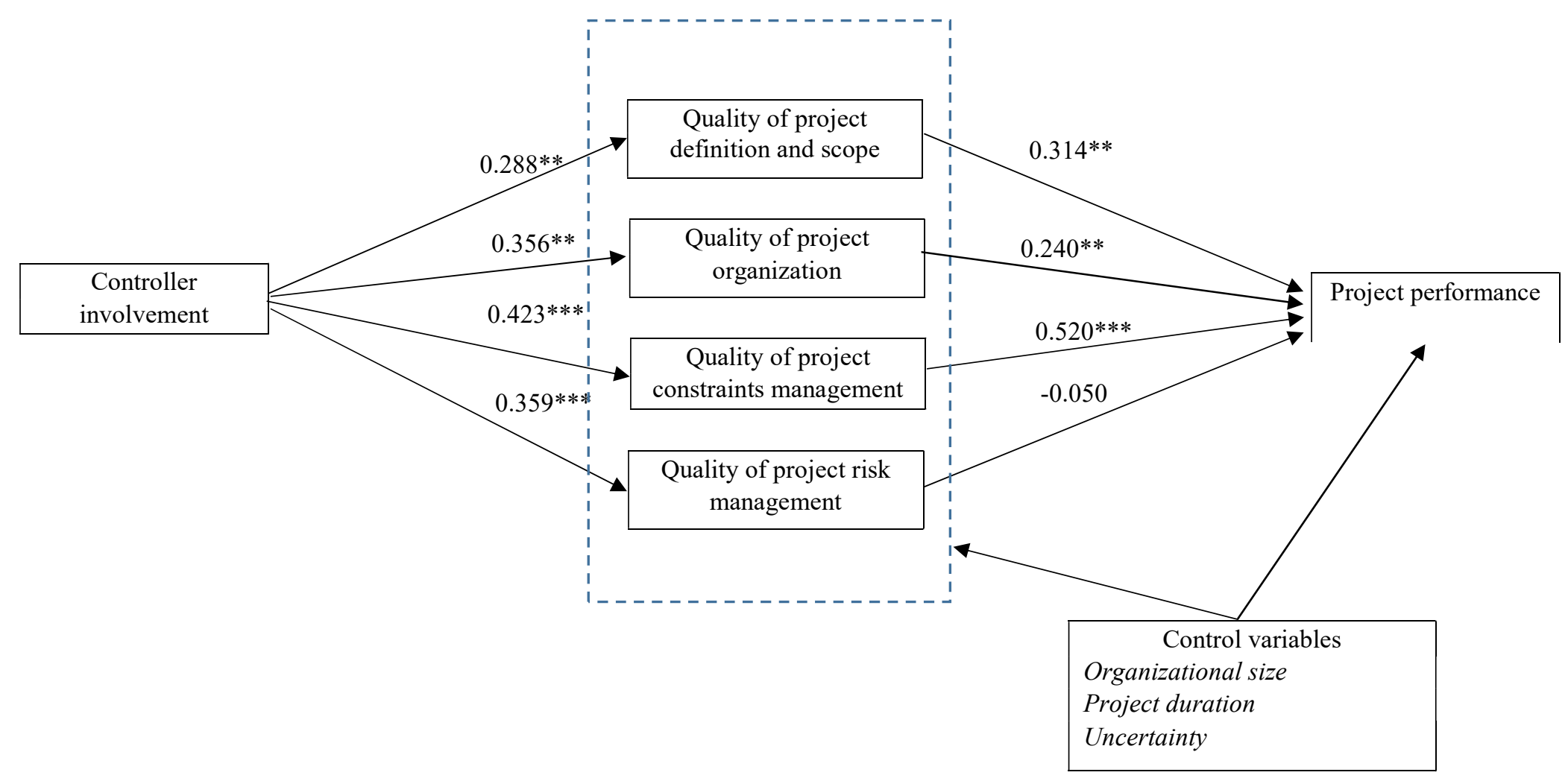

**,***: Significant at $5 \%$ and $1 \%$, respectively (Two-tailed tests).

Figure 2. Path model test results 